\title{
GEOLOGIC INTERPRETATION OF THE STUDY OF LUNAR ROCKS
}

\author{
LUBOMÍR KOPECKÝ \\ Geological Survey, Prague, Czechoslovakia
}

\begin{abstract}
The hypothesis on an internal origin of lunar rocks of gabbroic type is supported by experimental petrologic data obtained by the author. The temperature interval of their crystallization from a dry silicate melt is given.

Lunar gabbroic rocks of the Tranquillity Base are compared with paleobasalts of north-eastern Bohemia, eucrites and associated rocks of the British Isles and meteoritic eucrites of poikilophitic texture.

The metasomatic origin of lunar anorthosites displaying a mosaic texture in deeper parts of the volcanic apparatus is postulated.

An analogy is thought to exist between the Tertiary volcanic areas of Mull, Ardnamurchan and Rum in Scotland and the Ptolemaeus, Alphonsus and Arzachel regions of the Moon in the overall tectonic structure and the development of tectono-volcanic cirques. By analogy the possibility of the presence of more basic rocks in the rim and on the floor of the Moon subsidence calderas and of more acidic rocks of anorthositic to trachyandesitic chemistry in the central peak is presumed.

The mode of origin of double-craters of Cyrillus-Theophilus type is suggested to be similar to the origin of two consecutive volcanic rings of Mull.

The ring- and radial complexes of wrinkle ridges of Lamont type are compared with cone sheets and radial dykes of the central type tectono-volcanic complex of Mull.
\end{abstract}

\section{Introduction}

Lunar scientists are divided into two groups. Some are engaged in the direct study of the properties of the Moon and its rocks; the others are concerned with the published material on this subject and its interpretation. The latter group also includes a number of geologists who apply geological information about the Earth to analogous problems bearing on the Moon.

This contribution may be placed to the latter group and is based on published results of the studies of rocks from the Mare Tranquillitatis and Oceanus Procellarum.

\section{Crystallization of Lunar Magma}

Gabbroic rocks from the Mare Tranquillitatis, and especially from Oceanus Procellarum are strongly porous, with a frequent fluidal arrangement of the vugs, which is regarded justifiably as evidence of magma crystallization during surficial effusion [1]. The vug walls $(0.1 \mathrm{~mm}$ to $4 \mathrm{~cm}$ across) consist of crystals of olivine, pyroxene, plagioclase and other minerals composing the host rock (Figure 1). This suggests crystallization of so-called dry magma, a process which can be expected to occur in the Moon. The dry lunar magma is a melt that is devoid of most of the crystallizers under the conditions of low gravity and, at the Moon's surface, of high vacuum. If present, the crystallizers make possible the separation of crystals even at low temperatures during cooling of the magma. This process, however, enables the crystallization of 

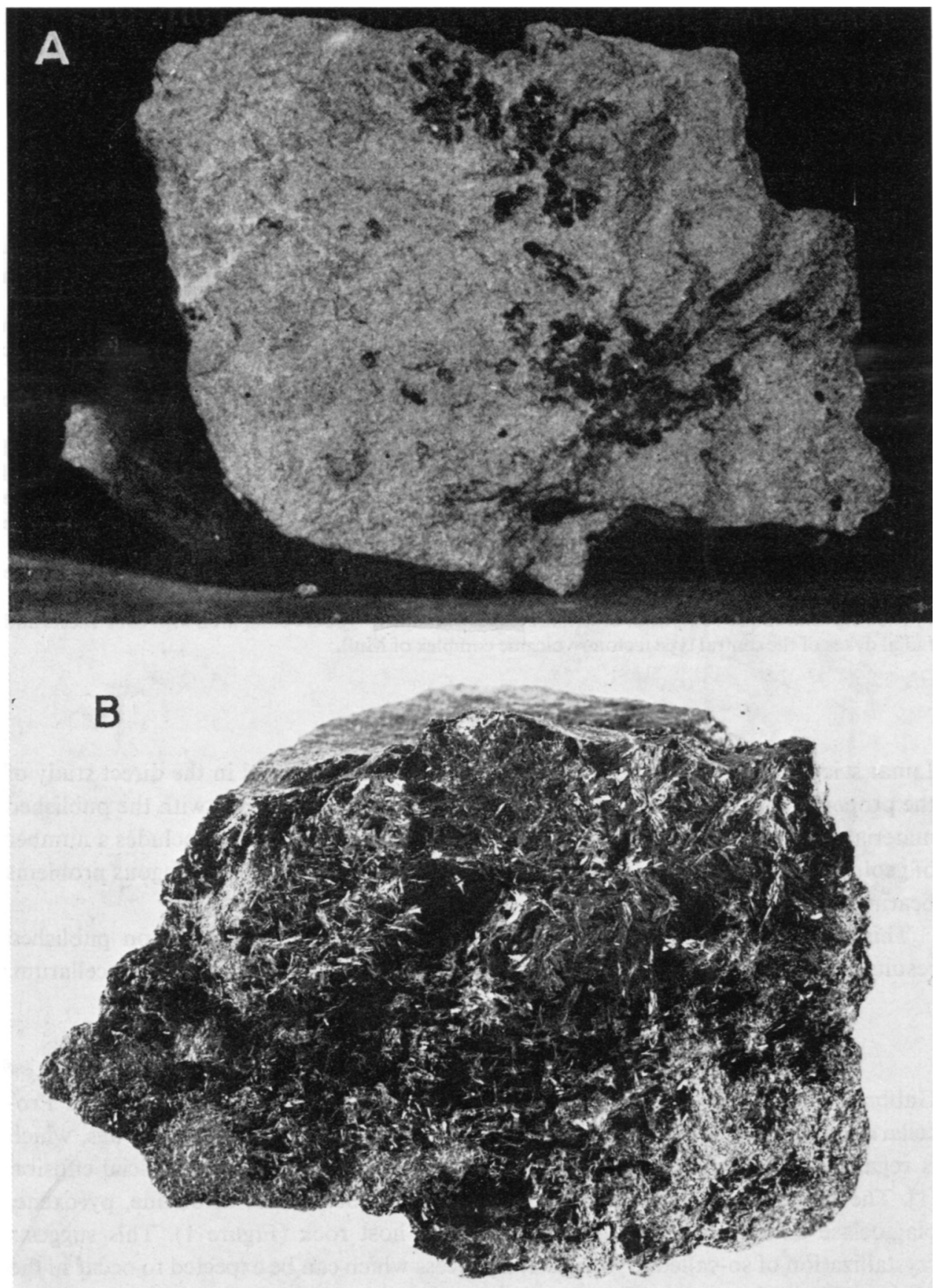

Fig. 1. Vugs in crystallized dry silicate melts. (a) Sample 12052, a typical equigranular crystalline Moon rock; vugs contain large euhedral crystals of pyroxene and olivine. NASA photo S-70-21320. (From Science 167, 1970). (b) Laboratory melted and crystallized alkali olivine basalt. The photograph shows a wall of a huge vug, which is covered by skeletal crystals of olivine and pyroxene. Actual size $6 \times 4 \mathrm{~cm}$. (Photo Geological Survey, Praha, Czechoslovakia.) 

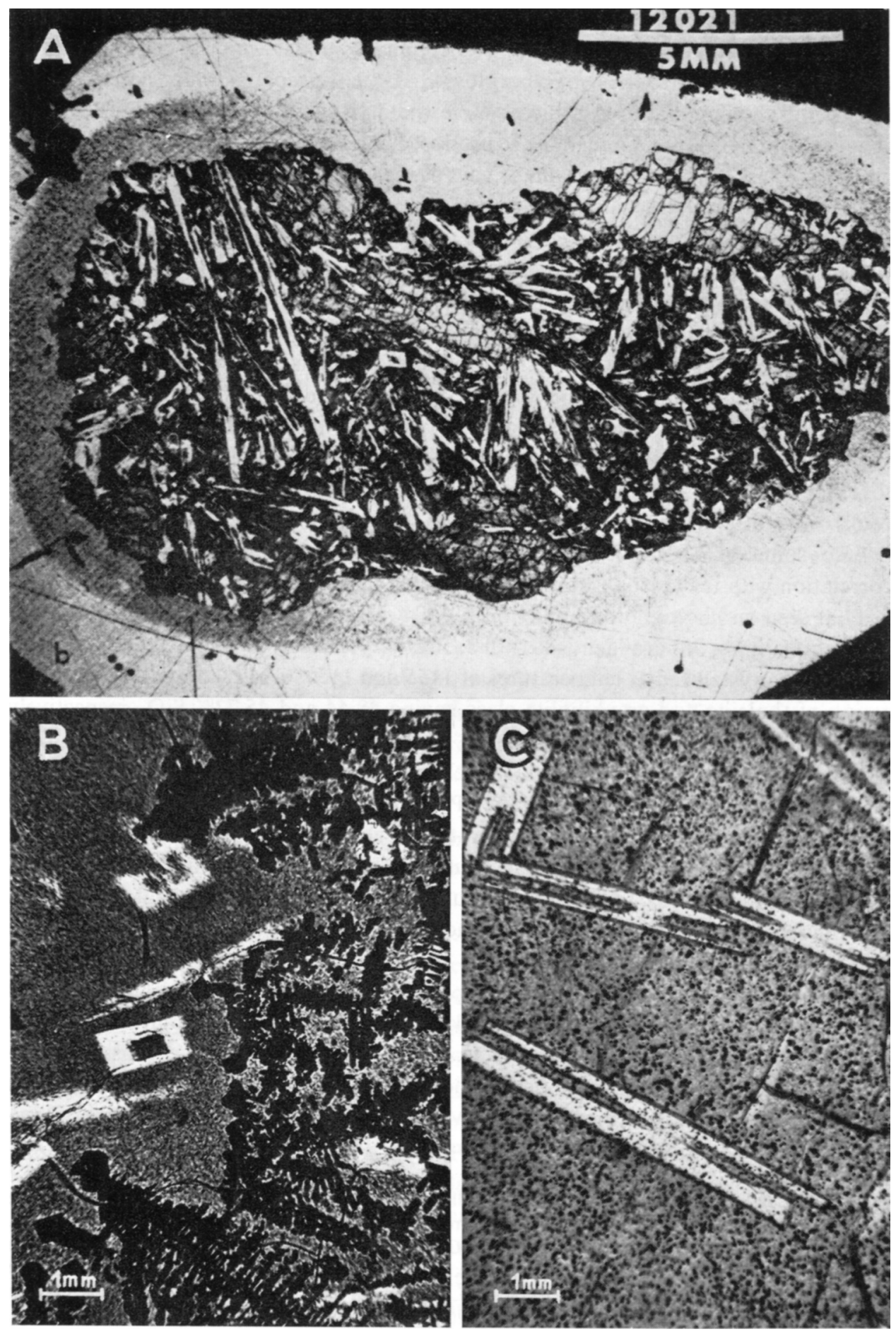

(For caption see p. 234.) 
hydatogenetic minerals such as amphiboles, micas, alkali feldspars, although these are rare in the lunar rocks examined. The conditions under which lava congealed on the Moon are similar to those of laboratory rock melts prepared under normal terrestrial atmospheric conditions, which enable the crystallizers to escape. During their solidification pyrogenetic minerals are produced, such as magnetite, olivine, pyroxene and plagioclase [2]. They form walls of vugs as they do in lunar basic rocks (Figure 1b).

The experimental crystallization of dry silicate melts from fused terrestrial rocks which had the $\mathrm{SiO}_{2}$ content of $38-45 \%$, i.e. near to that of crystalline rocks of $\mathrm{A}, \mathrm{B}$ types from Tranquillity Base, indicates that in this part of the lunar surface the rocks crystallized from magmatic effusions within the temperature interval of $1350-900^{\circ} \mathrm{C}$ under an abrupt withdrawal of crystallizers and drop of temperature [3]. This conclusion agrees with the results obtained by other methods as described elsewhere [4].

The consistent results of experiments conducted by different methods in different laboratories show the crystallization of dry silicate melts to be applicable for the study of crystallization temperatures of the Moon rocks. The temperatures deduced together with the structural history point to demonstrably volcanic origin of gabbroic rocks of the Moon.

Also some of photomicrographs of lunar rocks provide interesting data for correlation with the crystallization of dry silicate melts. Various shapes of plagioclase crystals seen on photomicrograph of spec. 10046 [5] and of similar volcanic rock spec 12021 [6] (Figure 2a) are identical with skeletal crystal shapes of plagioclase (bytownite) which crystallized at temperatures of 1155 and $1150^{\circ} \mathrm{C}$ at the fractional crystallization of tholeiite and amphibolite glass having 48.44 and $45.72 \% \mathrm{SiO}_{2}$ respectively (Figures 2b, c).

It can be concluded that the slightly skeletal forms of plagioclase from the samples taken at Tranquillity Base and Oceanus Procellarum could have separated from the rock melts with $38-45 \% \mathrm{SiO}_{2}$ at temperatures below $1150^{\circ} \mathrm{C}$. From the presence of skeletal forms a more rapid undercooling of the melt after effusion is inferable, probably close under the surface of the effusive body (to a depth of several decimetres). The influence of cooling of the lunar surface during the lunar night may also be taken into consideration.

In addition, the experimental petrographic observations exclude the impact origin of gabbroic rocks of lunar maria. It is well known that such extremely high temperatures as presupposed by high-velocity impact exclude any recrystallization of glass originated because of total loss of crystallizers and of liquidation of so-called crystallization seeds in the melt. But also the melting of Moon surface rocks by high pressure of low-

Fig. 2. Skeletal crystals as indicators of crystallization temperature of a silicate melt. (a) Sample 12021, a porphyritic gabbro with variolitic texture and with skeletal crystals of plagioclase. NASA, photo S-70-20749 (From Science 167, 1970). (b) Cross section of plagioclase crystals separated from the laboratory melt of paleobasalt from Stará Paka (Bohemia, Czechoslovakia) at the temperature of $1155^{\circ} \mathrm{C}$. Plane polarised. Photo L. Kopecký. (c) Longitudinal sections of skeletal plagioclase crystals separated from the amphibolite laboratory melt at the temperature of $1150^{\circ} \mathrm{C}$. Plane polarised.

(Photo L. Kopecký.) 
velocity impact cannot produce glass with good crystallization properties. Theoretically, this glass is highly undercooled at the time of its origin and its high viscosity does not enable sufficient movement of ions for crystallization.

Contrary to the opinions of Metcalfe and Barricelli [7], the crystallization history of lunar rocks clearly shows that their origin is internal and are hence not derived by impact of meteorites.

From structural development and mineral composition of the gabbroic to peridotite rocks from Mare Tranquillitatis and Oceanus Procellarum, it is possible to conclude, in accordance with experimental petrographical data, that the rocks are of igneous nature and crystallized from lava flows of normal volcanic origin.

\section{Some Terrestrial and Extra-Terrestrial Equivalents of the Main Lunar Rock Types from Mare Tranquillitatis and Oceanus Procellarum}

There are a number of comparisons in literature between the lunar gabbros and basalts from Mare Tranquillitatis, on the one hand, and the terrestrial rocks of basaltic composition, on the other. In this context basalts of Permian age have been recorded from New Zealand [5], basaltic rocks crystallized from residual solutions rich in $\mathrm{Fe}$ and $\mathrm{Ti}$ [8], or basalts building up ocean floors [9].

As far as structural history is concerned, analogous rocks also occur among the Permo-Carboniferous basalts (so-called melaphyres) of the Bohemian Massif [4]. The rock types composed of calcic plagioclase, Ti-bearing augite, olivine and magnetite fully agree with some A-type crystalline rocks from Mare Tranquillitatis in the poikilophitic texture and grain-size (Figures $3 a, b$ ). They differ from the lunar basalts only in the absence of cristobalite, the lower basicity of plagioclase, and the content of magnetite instead of ilmenite.

The rocks of the group of quartz gabbros and euerites from the Scottish islands show a still closer similarity to lunar gabbros and basalts (Figure 3c). Unlike normal terrestrial gabbroic rocks, the eucrites of Scotland are close to ilmenite melabasalts and dolerites from Mare Tranquillitatis as well as gabbros, diabases and basalts from Oceanus Procellarum especially in an extremely high basicity of plagioclases; a feature which is decisive in establishing the relationship of igneous rocks.

Plagioclases of the basic rocks from Mare Tranquillitatis correspond to $\mathrm{An}_{64}-\mathrm{An}_{90}$ [10], $\mathrm{An}_{71}-\mathrm{An}_{87}$ [8], $\mathrm{An}_{60}-\mathrm{An}_{100}$ [11], $\mathrm{An}_{78}-\mathrm{An}_{93}$ [12], $\mathrm{An}_{73}-\mathrm{An}_{81}$ [13], [14]. Labradorite is reported to predominate. Plagioclases of the basic rocks from Oceanus Procellarum correspond on the average to $\mathrm{An}_{50}-\mathrm{An}_{90}$, their average value also corresponding to labradorite $\left(\mathrm{An}_{80}\right)$ [6]. Plagioclase coming from the quartz gabbros to eucrites from Ardnamurchan Peninsula is bytownite to anorthite [15]. According to Richey, the quartz gabbro forming a marginal facies of the Great Eucrite of Ardnamurchan displays an ophitic texture, contains olivine and a high amount of iron ore. In essence, it differs from the lunar basalts only by the presence of quartz instead of cristobalite and by the content of magnetite instead of ilmenite. It has been established that the high ilmenite content is a specific feature of the rocks coming from Mare 


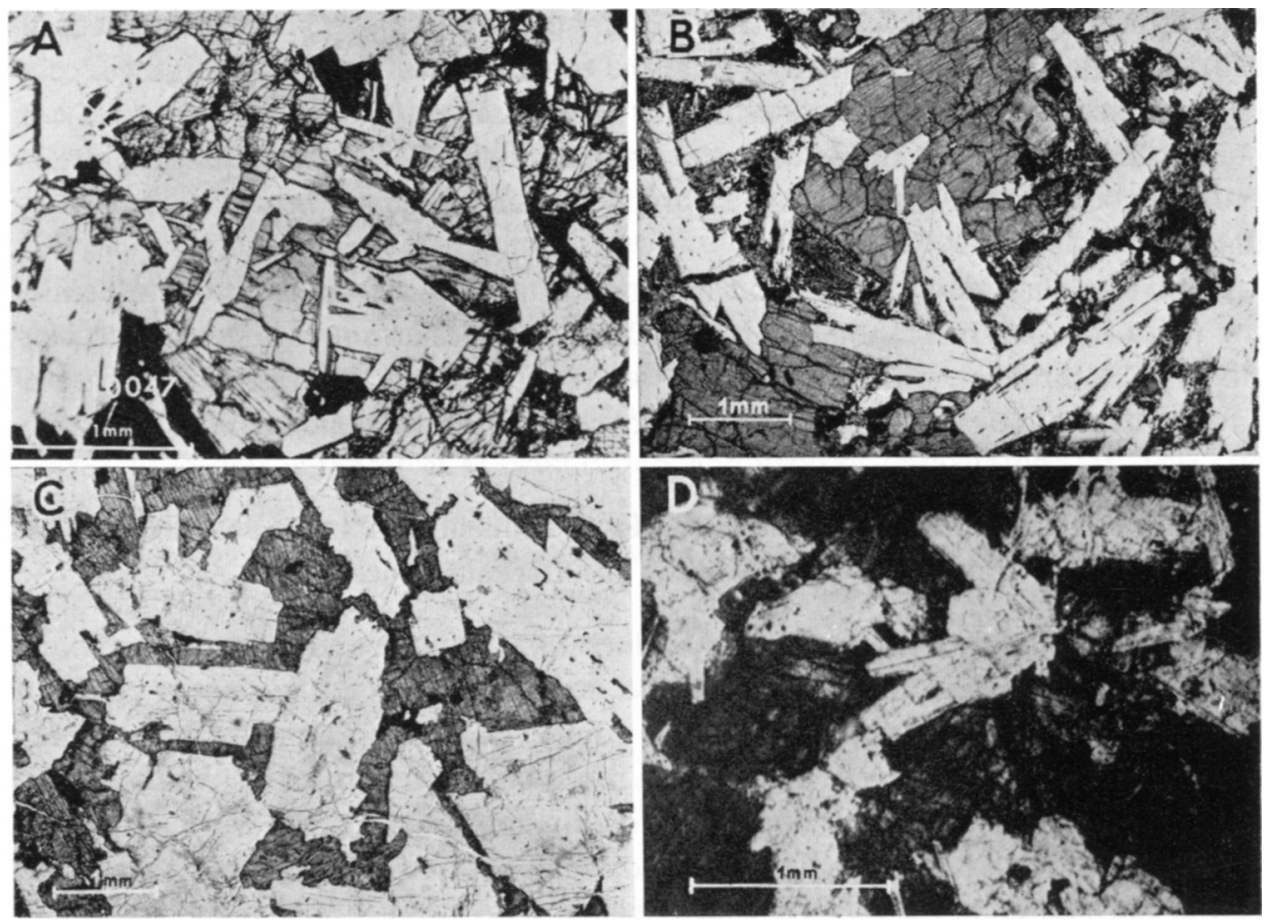

Fig. 3. Textures of the Moon, terrestrial and meteorite basaltic and eucritic rocks. (a) Poikilophitic texture of crystalline rock 10047 of Tranquility Base; the rock consists of Ca-rich plagioclase, clinopyroxene, ilmenite, minor olivine and cristobalite, and accessory minerals. Plane polarised. NASA, photo S/69-47907. (From Geotimes, October 1969.) (b) Similar texture and major mineralogy of terrestrial Upper Paleozoic basalt from NE-Bohemia (Czechoslovakia) - as shown in Figure 3a. Plane polarised. Geological Survey, Praha, photo 24336. (c) Poikilophitic texture of olivine eucrite from Ardnamurchan (near Lighthouse), Scotland. Plane polarised. Geological Survey, Prague, photo 26924. (d) Poikilophitic texture of eucrite material composed of pigeonite and bytownite and included in the Mt. Padbury meteorite. Plane polarised. (From G. J. H. McCall, 1966.)

Tranquillitatis, whereas the rocks from Oceanus Procellarum are poorer in ilmenite. Cristobalite in these lunar rocks resulted from crystallization of a dry rock melt, intrusive rocks of the Scottish circular complexes crystallized with a sufficient amount of water for the origin of quartz.

Of extra-terrestrial objects, the stony meteorites of eucrite-type composed essentially of pyroxene and anorthite may best be compared with lunar gabbros and basalts. As was pointed out by Shand [16], the meteorites with less than $10 \%$ of nonsilicates highly resemble terrestrial igneous rocks. As was stated by Shand (as referred to by C. Rammelsberg), the frequently cited eucritic inclusion in the metallic meteorite from Juvinas (Figure 3d) has the same mineral composition as the anorthite gabbro. Furthermore, it displays a similar poikilophitic texture which suggets analogy between the meteoritic eucrites, lunar gabbros and terrestrial eucrites, which were named after the former (G. Rose in 1835). 

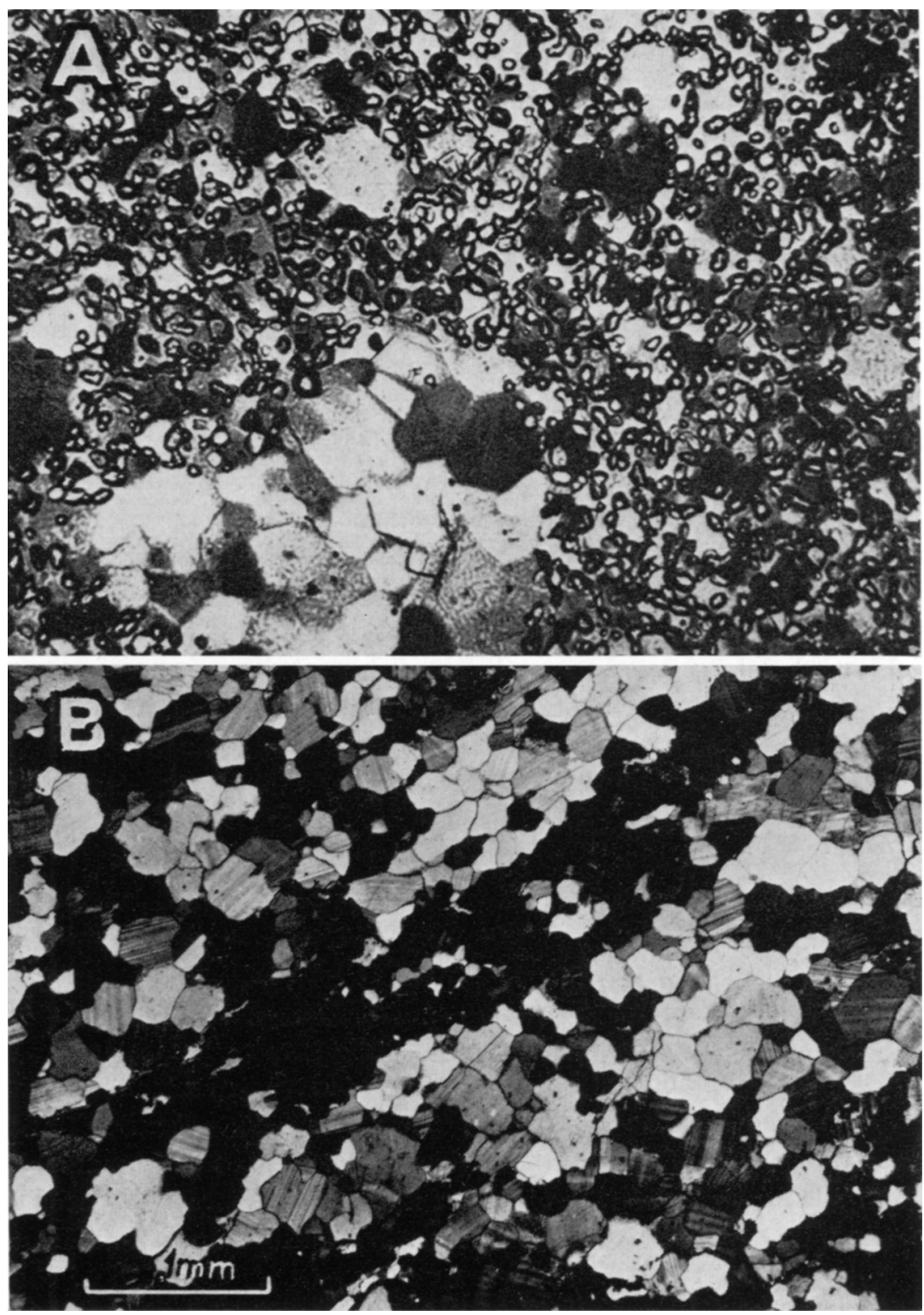

Fig. 4. Texture of the Moon anorthosite. (a) Gabbroic anorthosite with clots of true anorthosite. The polygonal (mosaic) texture of anorthosite may have formed by recrystallization. Oblique nicols. (From J. A. Wood et al., 1970). (b) The same texture of alkaline metasomatic rock (fenite) from the České středohoři Mts. in Czechoslovakia; the polygons are made up of alkalic feldspars. Oblique nicols. (Photo L. Kopecký.) 
According to Tschermak's view [17], which was later supplemented by von Wolff [18], stony and also metallic meteorites showing frequent brecciated structure of tuffaceous nature may represent ejecta of volcanic explosions produced by small cosmic bodies. Again, there seems to exist an analogy with the basic intrusive rocks of the Scottish islands, where repeated intrusions and explosions gave rise to brecciated eucrites.

The comparison of mineral composition and structural history of the lunar and terrestrial rocks of the gabbroic to eucritic types with meteoritic eucrites indicates that all these rocks originated in a similar manner. If the terrestrial eucrites and basalts are the crystallization products of magma intruded under or extruded on the Earth's surface during volcanic activity, then the above analogies prove unequivocally the magmatic origin of the lunar rocks discussed.

Lunar gabbros resemble lunar anorthosites in the composition of feldspars. Transitional types have been differentiated up to the anorthosite gabbro. The igneous origin of gabbroic to peridotite lunar rocks is accepted generally but the genesis of lunar anorthosites is not unambiguous. It is well known, however, that neither terrestrial anorthosites are regarded as igneous rocks by all geologists. Polygonal (mosaic) texture of lunar anorthosite (Figure 4a), uncommon in magmatic rocks, is explained by the accumulation of the early crystallizing plagioclase, although the possibility of its origin by recrystallization has also been suggested [19]. This view is supported by the comparison with polygonal textures of the terrestrial metasomatic rocks (Figure $4 b$ ). Finally there exists no reason for excluding the possibility that metasomatic rocks on the Moon are the result of thermal activity under the supply of material in the subsurface parts of volcanic apparatuses of large subsidence calderas.

Wood [19] compared chemical composition of the anorthosites from the breccias in the regolith of Mare Tranquillitatis with an analysis of ejectamenta of the crater Tycho, carried out by Surveyor 7. He believed the analysis to be clearly related. Anorthosites and more acid rocks may thus genetically be referred to large circular tectono-volcanic structures and volcanoes of the central type of terrae, including the crater Tycho. They can make up their central peaks often of very light colour, as is documented by the central peak of the crater Tsiolkovsky. This is in agreement with the principle that the rocks become more acid towards the centre of circular volcanic complexes of the Earth. There is also an analogy with central anorthosite elevation of the crater Manicouagan lying in the Canadian Shield (Figure 5) [20]. A high albedo suggests that some isolated mounts as well as domes in the maria or at the margins of the terrae may also belong to anorthosites. The presence of anorthosites in the terrae also corresponds to their low density $\left(2.9 \mathrm{~g} \mathrm{~cm}^{-3}\right)$. Gabbroic rocks fill tectono-volcanic depressions of the maria together with peridotitic rocks of a higher density. The average density of gabbroic rocks $\left(3.4 \mathrm{~g} \mathrm{~cm}^{-3}\right)$ which together with still heavier peridotitic rocks fill the tectono-volcanic depressions of maria, must be compensated for by lighter masses of the lunar crust within the area of terrae, so that average density value $\left(3.34 \mathrm{~g} \mathrm{~cm}^{-3}\right)$ would be preserved. 


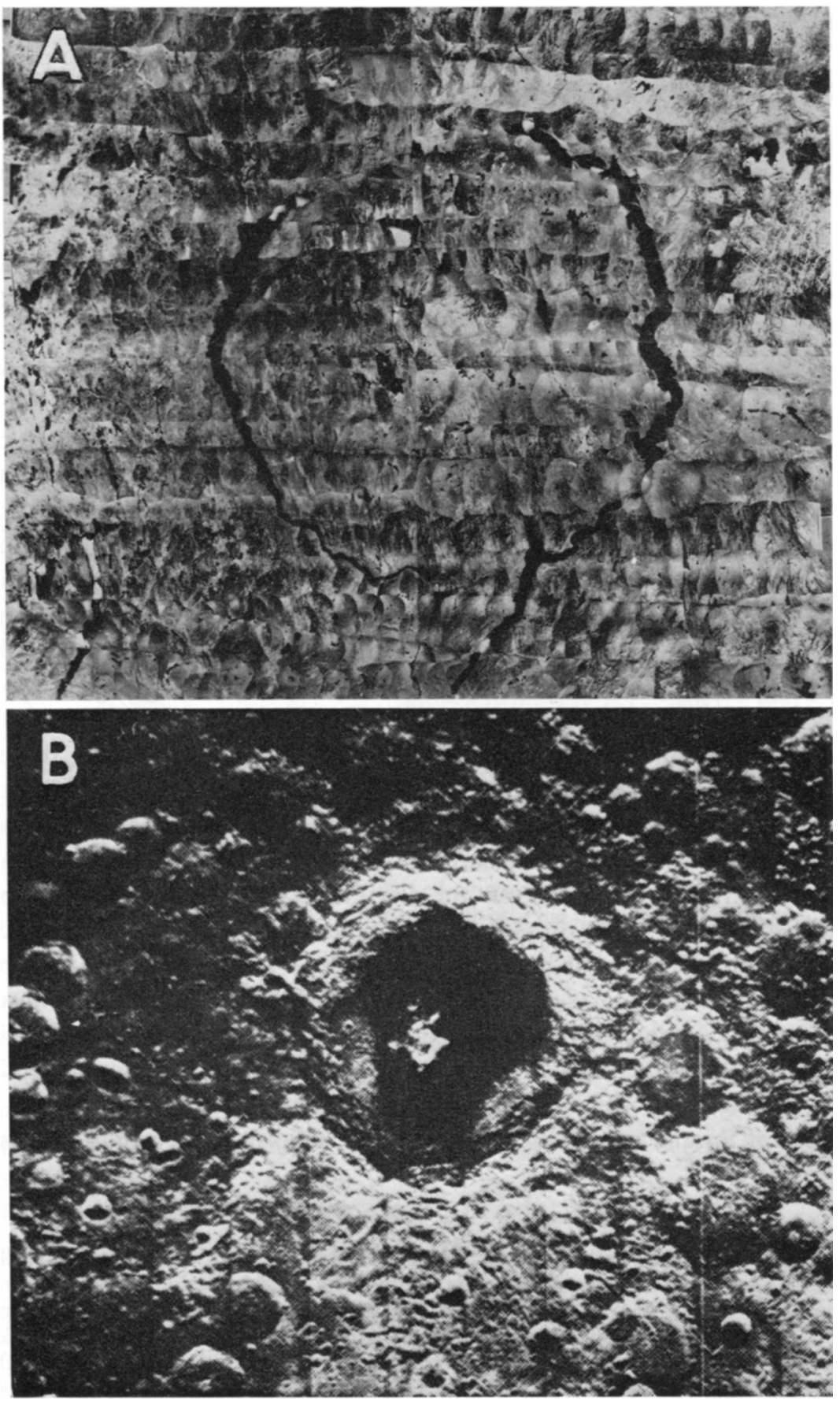

(For caption see p. 240.) 
From the aforesaid conditions and assumptions it can be deduced that the accumulation of heavy masses in the maria (causing strong gravimetric anomalies) may also be responsible for the present-day passive rotation of the Moon [4].

\section{Analogy of Tectono-Volcanic Structure of the Scottish Islands and Some Important Structures of the Lunar Crust}

It is believed that the existence of basaltic volcanism in the maria is well evidenced, but it is not yet known with certainty (according to the Apollo 11 and Apollo 12 samples investigation results) whether it does occur in the terrae. This concerns, e.g., the dark spots on the bottom of Alphonsus crater [21] or the dark material composing bottoms of the large circular structures.

Assuming that the anorthosite material of the lunar breccia from the regolith of Mare Tranquillitatis is derived from the terrae [19], it is necessary to assume that anorthosite fragments were transported from the terrae to mare regolith together with a certain amount of the rocks of gabbroic to peridotite composition. It must then be adopted that a certain number of the fragments of basalts, gabbros and peridotites coming from a mare regolith, which were brought by Apollo 11 and 12, represent volcanic material that builds up (together with anorthosites) circular and polygonal continental formations. Furthermore, it may be deduced that the two types of lunar basic rocks, those of the maria and terrae (continents), do not differ essentially from one another. Hence, the basalts from the terrae are comparable with the eucrites (eucritic rocks) of the Earth.

Taking into account all what has been said above, comparison can be made between rock associations of the regolith of maria and analogous rock associations composing the volcanic circular complexes on the Earth. Such comparison is possible, for example, between the rocks from Mare Tranquillitatis and Ardnamurchan in Scotland (basalts, ilmenite gabbro, anorthosite gabbro, gabbroic anorthosite from the Apollo 11 collection, and gabbro, quartz gabbro and eucrites from Ardnamurchan Peninsula), or the rocks from Oceanus Procellarum and Rum in Scotland (pyroxene peridotite, olivine gabbro, gabbro and troctolite from the Apollo 12 collection and peridotite, anorthosite peridotite and eucrite of intrusive complexes of Rum).

If we adopt Spurr's application of Richey's principle of the cauldron subsidence

Fig. 5. Possible analogy between central anorthosite elevation of big cratonic craters on the Earth and central peaks of high albedo in big ring structures on the Moon. (a) The cratonic crater of Manicouagan in Canada is a tectono-volcanic ring of cauldron-subsidence origin. According to K. L. Currie (1965) it is a polygonal depression of a diameter of $60 \mathrm{~km}$ and with a central elevation. The depression is surrounded by a tectonic fracture at the surface filled with water (dark rim), and is covered by breccias and partly by andesite and basalt lavas. The central elevation is made up of anorthosite which is marked by its light colour on the photograph. Photo credit to the Geological Survey of Canada. (b) The ring structure Tsiolkovsky on the Moon displaying a light central elevation and dark bottom, possible flooded by a basic lava. Diameter about $240 \mathrm{~km}$ (150 miles). North to the left. (From NASA SP-168: Exploring space with a camera, by E. M. Gortright, 1968.) 

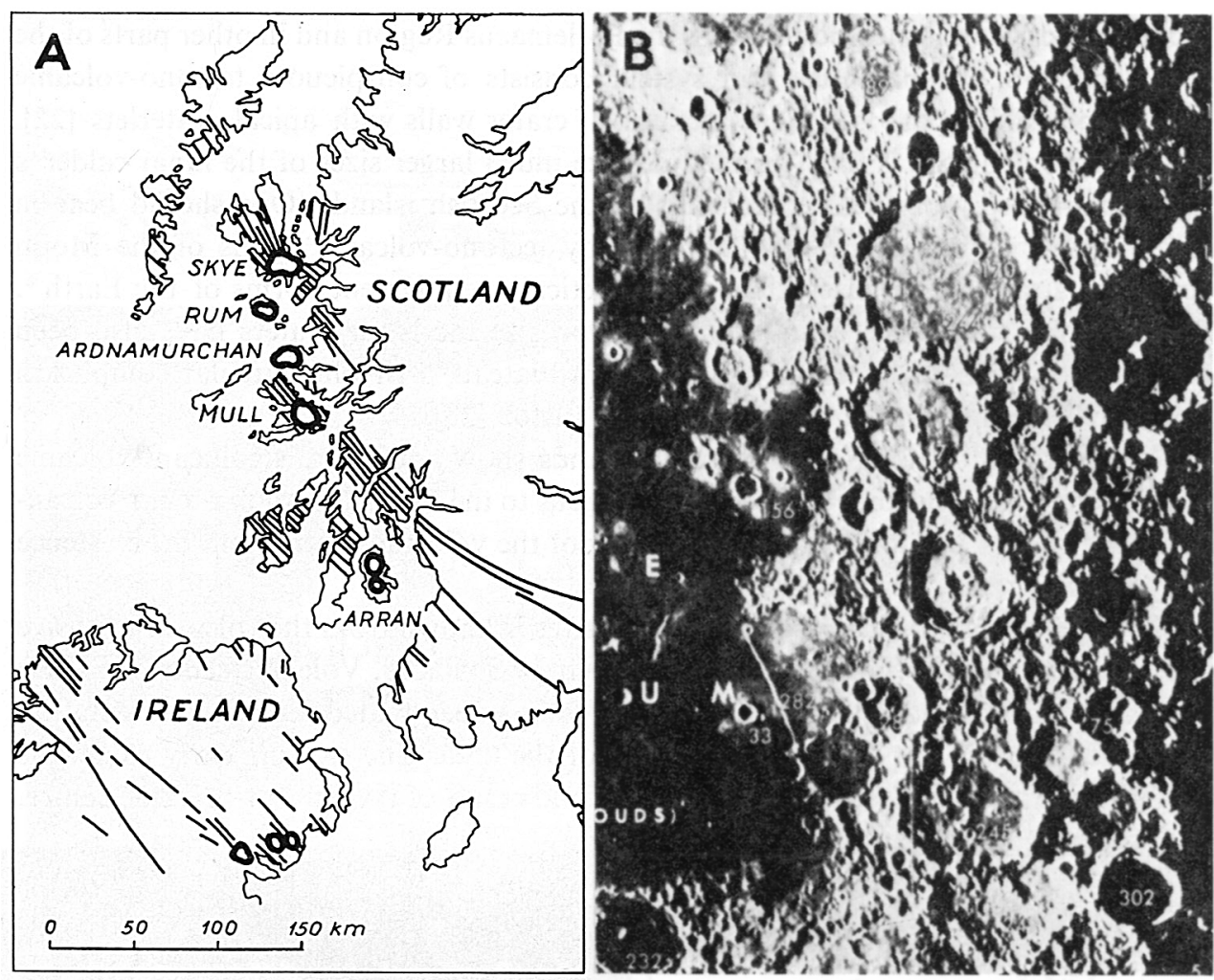

Fig. 6. Analogy of geological surface structure between the Moon and Earth. (a) The terra-mare boundary and the area of tectono-volcanic ring complexes Ptolemaeus, Alphonsus and Arzachel on the Moon, with a pronounced NW lineation marked by parallel ridges and valleys. (b) The area of central eucrite intrusion complexes of Scottish Islands display the same relation of tectonic lineation to the volcanic rings. The lineation is marked by basic dykes.

for the explanation of the origin of large lunar craters (circular structures), it is evident that there is an analogy between the lunar circular and polygonal subsidence calderas and central intrusive complexes of Scotland, not only in rock-type association but also in a detailed geological structure - except for the different degree of denudation (Figure 8).

Another striking analogy has also been observed in the geological structure of a wider area between the circular complexes of Skye, Ardnamurchan, Mull and Rum and the polygonal subsidence calderas of Ptolemaeus, Alphonsus and Arzachel (Figure 6). This analogy is documented by the following: (i) both regions were strongly affected by planetary tectonics trending north-northwest; (ii) the distribution of the individual subsidence calderas and their areal relationship to the zone of strong tectonic disturbance; (iii) and the detailed interaction of tectonic and volcanic activities within each of the calderas. In the Scottish Islands planetary tectonics effects are stressed by swarms of linear dykes of dolerite, basalt and augite andesite following the course of 
the so-called second volcanic zonal. In the Ptolemaeus Region and in other parts of the continents too, the panlunar grid system consists of conspicuous tectono-volcanic linear septa which pass into ridge sections of crater walls with apical craterlets [22].

Such a comparison is fully justified despite much larger sizes of the lunar calderas than attain their terrestrial equivalents of the Scottish islands. One should bear in mind that it is yet insufficiently known why tectono-volcanic forms of the Moon generally attain larger sizes than the genetically equivalent forms of the Earth*. Furthermore, subsidence calderas equalling in size the lunar craters have also been observed on the Earth, such as the Mogollon Plateau, a rhyolite circular complex in southern New Mexico, USA, as described by Elston [23].

The central intrusions of the Scottish islands show additional significant volcanic phenomena which may be regarded as analogous to the forms of circular lunar volcanism. This relates particularly to the shifting of the volcanic centres and the existence of systems of radial and circular dykes.

The classic form of shifting of volcanic centres is known from the volcanic intrusive circular complexes of Mull and Ardnamurchan in Scotland. Volcanic centres of these two islands moved along an axis [24] - apparently a deep-seated fault - the orientation of which is defined by the main lineament of the area. The existing early caldera is partly obliterated and buried by a late caldera in result of the shift of volcanic centre.
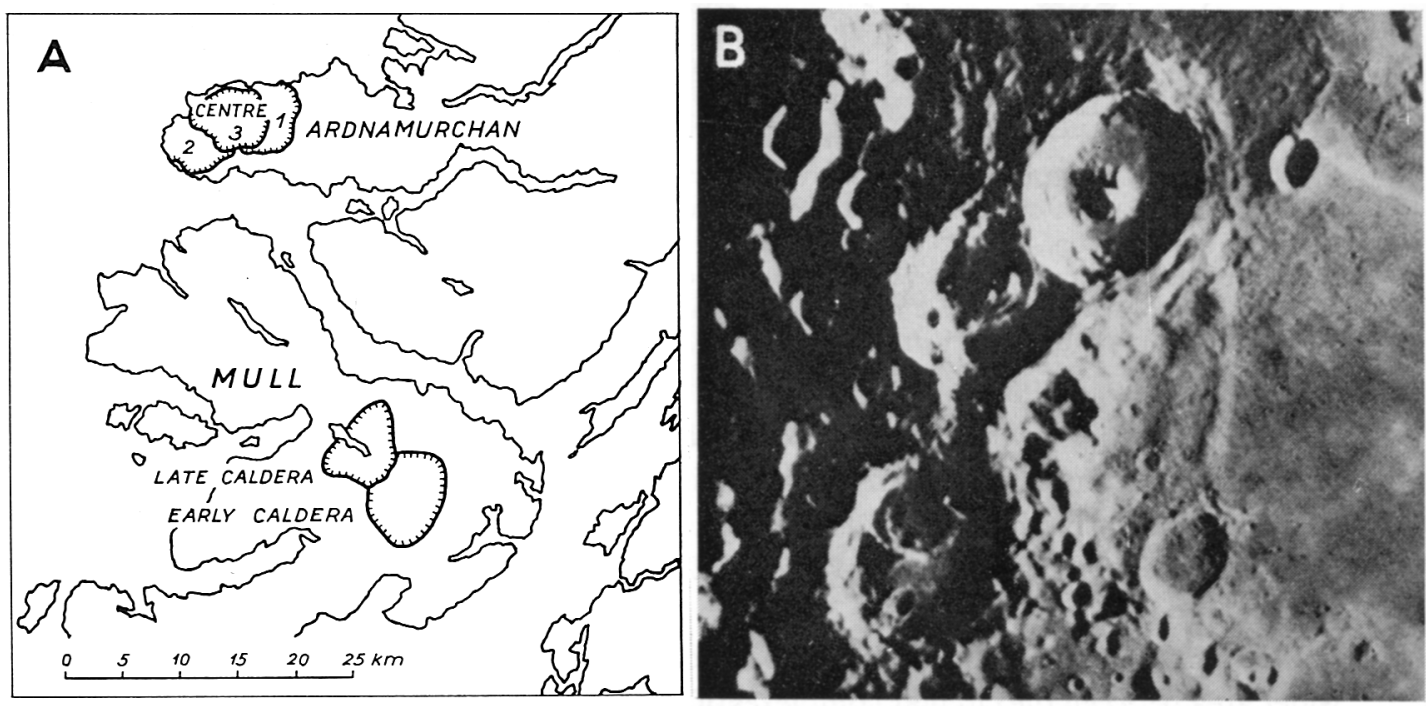

Fig. 7. Caldera doublets on the Earth and Moon. (a) The shifting of eruption centres of Scottish central intrusion complexes of the Mull and Ardnamurchan. The surface morphology of calderas has been effaced by denudation. In the sketch the margins of early and late calderas of Mull and three subsequent plutonic-vent complexes (centre 1-3) of Ardnamurchan are drawn. (From J. E. Richey, 1961.) (b) The doublet of subsequent equal tectono-volcanic ring complexes of Cyrillus (the older eruption centre) and Theophilus (the younger one) on the Moon. Surface volcanic morphology is preserved. (From the Photographic Atlas of the Moon by Z. Kopal, 1965.)

* A possibly higher thickness of the Moon's crust or its different mechanical properties as compared with the Earth's crust. 

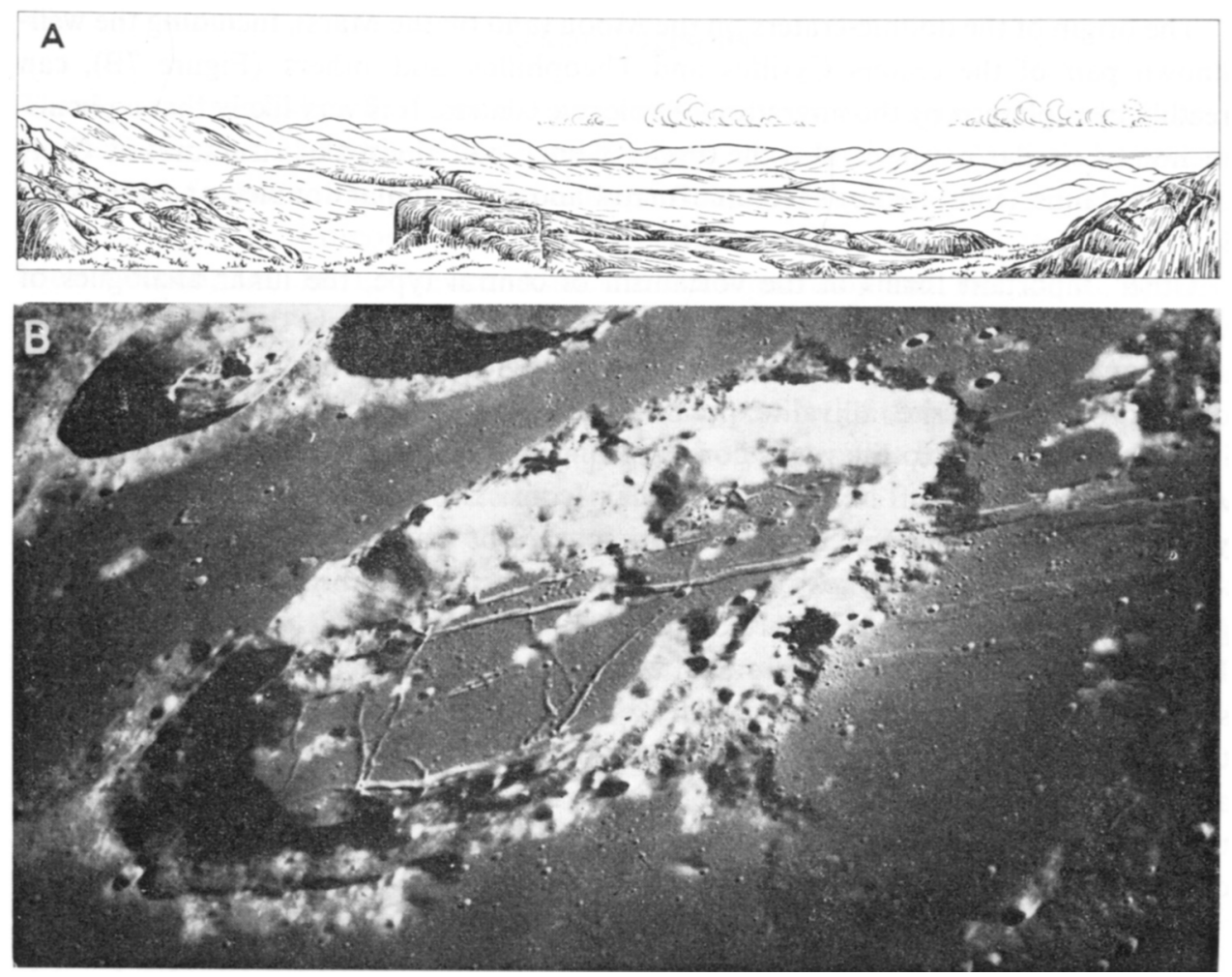

Fig. 8. The analogy of intrusive ring complexes of Scottish Islands and tectono-volcanic rings on the Moon. (a) Panorama of Great Eucrite and interior complex of ring-dykes of centre 3, Ardnamurchan. Outer ring of hills and dark foreground mark the outcrops of Great Eucrite. Low inner ring surrounding central knob of quartz-monzonite is the fluxion biotite-gabbro of Gledrian. Diameter $4.8 \mathrm{~km}$ (From J. E. Richey, 1961). (b) Apollo 8 view of the ring structure of Goclenius, nearly $64 \mathrm{~km}$ from rim to rim. Photo CP 34430/26, Project Apollo 8 (Original NASA photograph kindly offered by the U.S.A. Embassy in Czechoslovakia). Origin of both these types of ring structures is due to the cauldron subsidence phenomena. Also the deep structure and chemism may be analogous, only the degree of erosion differs. Note younger tectonic fractures crossing both, the terrestrial and the lunar circs.

Such displacement may be simple (as is the case with Mull) or complex (as with three volcanic centres in Ardnamurchan, Figure 7a).

The youngest centre of Ardnamurchan Peninsula morphologically resembles lunar circs with a central peak and an outer wall (Figure 8). It is 5 by $6.5 \mathrm{~km}$ in diameter, and consists of a set of circular dykes. Proceeding from the margin toward the centre the dykes are formed by gradually younger and more acid intrusions of gabbro, eucrite, quartz gabbro, eucrite, quartz dolerite, quartz gabbro, tonalite, and quartz monzonite of plutonic dimensions. As already mentioned above, this rock association is very similar to that of the regolith from Mare Tranquillitatis. Judging by the presence of anorthosite fragments, it must be assumed that in Mare Tranquillitatis is an abundance of rock material derived from the tectono-volcanic circular depressions of the terrae. 
The origin of the double-craters on the Moon (and on the Mars), including the wellknown pair of the craters Cyrillus and Theophillus and others (Figure 7B), can readily be explained by the migration of volcanic centres. It is very likely that a phenomenon of similar nature is also the origin of such paired circular structures as Craft and Cardanus, connected by a tectonic furrow and other similar doublets and triplets of lunar circs that lie on their common axis.

Other important forms of the volcanism of central type, the lunar analogues of which may be seen especially in wrinkle ridges of mare regions are the systems of cone sheets and radial dykes. Island Rum, a classical region of such central rock intrusions of rocks such as eucrite, allivalite, peridotite and gabbro, provides a good analogy in its rock associations to the rocks coming from the regolith of Oceanus Procellarum. A younger complex of cone sheets of Rum consists of gabbro and eucrite, and a youngest system of radial dykes comprises various basic rocks (Figure 9a). The system of these young dykes may also be regarded as possibly analogous, both in geological structure and mineral composition, to some typical lunar mare regions. Lamont, a system of circular and radial wrinkle ridges, north of the Apollo 11 landing site (Figure 9b), highly resembles the dyke complex of Rum. It has been established that systems of the wrinkle ridges generally show a similar orientation in all circular and polygonal maria. The wrinkle ridges may rightfully be interpreted as manifestations of the latest volcanism of central type of the maria [25] the largest lunar subsidence calderas - as they were called by von Bülow [26].
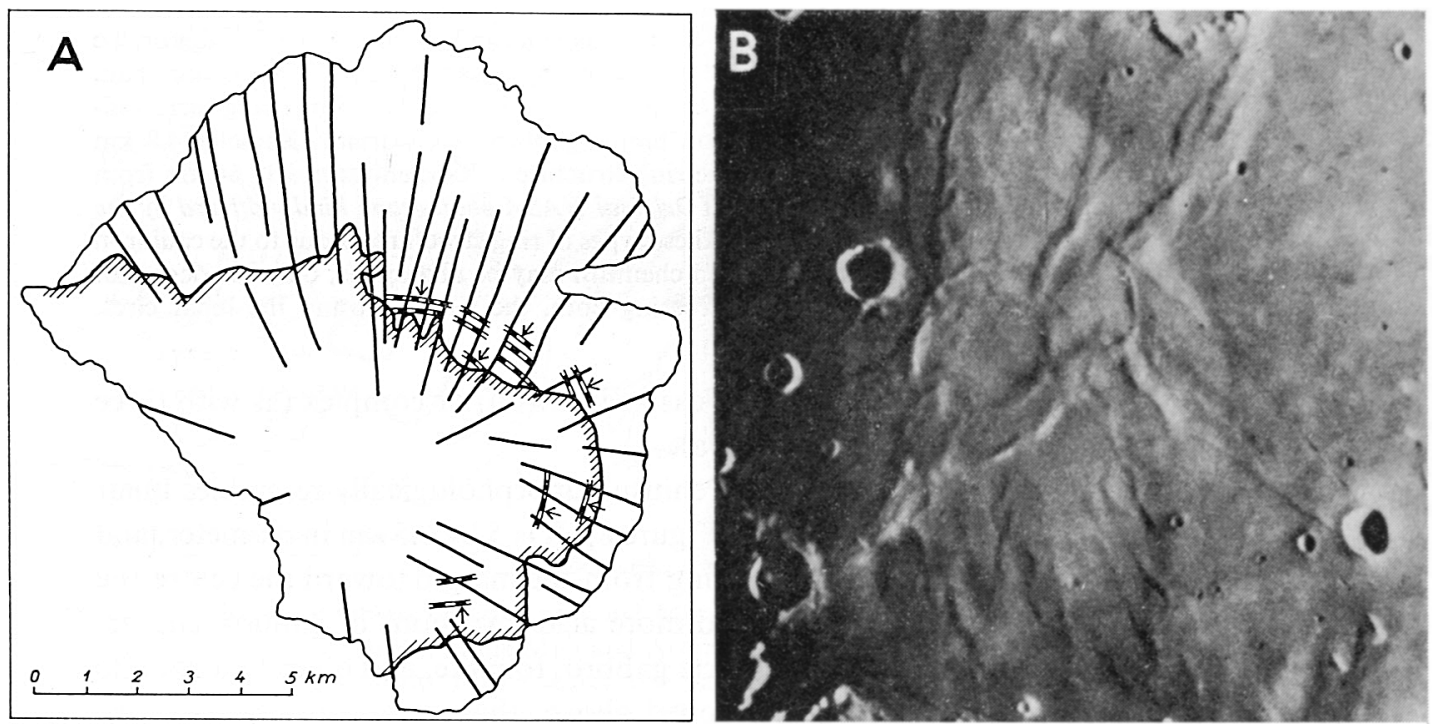

Fig. 9. Radial dykes and cone-sheets intrusion complexes on the Earth and on the Moon (a). Trends of an eroded complex of radial dykes and cone-sheets of the Scottish island of Rum (From J. E. Richey, 1965). (b) Analogous structure of radially oriented and circularly shaped wrinkle ridges of the complex of Lamont in the Mare Tranquillitatis suggest that wrinkle ridges are linear volcanic features of deep-seated phoci. 


\section{Acknowledgments}

Thanks are due to the officers of the American Embassy in Prague, especially to Mr. A. T. Falkiewicz, the former Press and Cultural Attaché, Mr. S. Vaňáč and Mr. J. Zábranský, farther to Dr. K. L. Currie, Department of Energy, Mines and Resources, Canada, Dr. R. E. Corcoran, Director, Department of Geology and Mineral Industries, Oregon, Dr. H. E. Newel, Associate Administrator and Dr. D. R. Morris, Deputy Assistent Administrator for International Affairs, NASA, and to $\mathrm{Mr}$. $\mathrm{H}$. Arnett, Pacific Power and Light Company, Wyoming, for the papers and photographs on this subject, and to Dr. H. J. Moore for the set of the Geologic Map of the Moon, which all would have otherwise been hardly accessible to the author.

Special thanks are expressed to Dr. J. Green, President of the IAP, for his revision of the manuscript. Professor S. K. Runcorn, Editor of the Symposium Proceedings, is highly appreciated for his personal assistance in preparing this paper for print.

Finally the author is highly grateful to Mr. A. Mackensie Smith, the Cultural Attaché, British Embassy in Prague, for his help in maintaining the author's correspondence with the Editor in early spring 1971.

\section{References}

[1] Lunar Sample Preliminary Examination Team: 1969, Science 165, 1211.

[2] Kopecký, L. and Voldán, J.: 1965, Ann. N.Y. Acad. Sci. 123, 2.

[3] Kopecký, L.: 1970, Geologický průzkum XII, 6.

[4] Summary of Apollo 11 Lunar Science Conference: 1970, Science 167, 449.

[5] King, E. A. Jr., Carman, M. F., and Butler, J. C.: 1970, Science 167, 650.

[6] The Lunar Sample Preliminary Examination Team: 1970, Science 167, 1325.

[7] Metcalfe, R. and Barricelli, N. A.: 1970, Moon 1, 2.

[8] Anderson, A. T., Jr., Grewe, A. V., Goldsmith, J. R., Moore, P. B., Newton, J. C., Olsen, E. J., Smith, J. V., and Wyllie, P. J.: 1970, Science 167, 587.

[9] Katterfeld, G. and Shulz, S, Jr.: 1971. Porody lunnygh moreiy. Naukaizizn 2, Moskva.

[10] Keil, K., Prinz, M., and Bunch, T. E.: 1970, Science 167, 597.

[11] Douglas, J. A. V., Dence, M. R., Plant, A. G., and Traill, R. J.: 1970, Science 167, 594.

[12] Brown, G. M., Emeleus, C. H., Holland, J. G., and Phillips, R.: 1970, Science 167, 599.

[13] Kushiro, I., Nakamura, Y., Haramura, H., and Akimoto, S. I.: 1970, Science 167, 610.

[14] Weill, D. F., McCallum, I. S., Bottinga, Y., Drake, M. J., and McKay, G. A.: 1970, Science 167, 635.

[15] Richey, J. E.: 1933, Geol. Assoc. XLIV, 1.

[16] Shand, J.: 1950, Eruptive Rocks, London, New York.

[17] Tschermak, G.: 1875, Sitzber. Math.-Naturw. Kl. K. Akad. Wiss. 71, II, Wien.

[18] von Wolff, F.: 1914, Der Vulkanismus, I, Stuttgart.

[19] Wood, J. A., Dickey, J. S., Jr., Marvin, U. B., and Powell, B. N.: 1970, Science 167, 602.

[20] Currie, K. L.: 1965, Ann. N. Y. Acad. Sci. 123, 2.

[21] Green, J.: 1966, 'Lunar Exploration and Survival', Advanced Research Laboratories, Douglas.

[22] McCall, G. J. H.: 1965, Ann. N.Y. Acad. Sci. 123, 2.

[23] Elston, W.: 1965, Ann. N. Y. Acad. Sci. 123, 2.

[24] Richey, J. E.: 1961, British Regional Geology, Scotland', The Tertiary Volcanic District, Edinburgh.

[25] Cattermole, P.: 1967, 'The Nature and Origin of the Lunar Maria', Sborník věd. prací Vys. školy báňské v Ostravě, ̌̌ada horn.-geol., zvl. číslo, Ostrava.

[26] von Bülow, K.: 1965, Ann. N. Y. Acad. Sci. 123, 2. 